\title{
Implementation of the Small Claims Court in Dispute Case Settlement in Indonesia
}

\author{
Seno Adhi Wibowo \\ Faculty of Law, Universitas Negeri Semarang, Semarang, Central Java, Indonesia \\ Email: senoadhi@students.unnes.ac.id \\ ORCID Link: https://orcid.org/0000-0001-5999-8184 \\ Massulthan Rafi Wijaya \\ Faculty of Law, Universitas Negeri Semarang, Semarang, Central Java, Indonesia
}

\section{Citation:}

Wibowo, S. A., Wijaya, M. R. (2021). Implementation of the Small Claims Court in Dispute Case Settlement in Indonesia, Lex Scientia Law Review, 5(1), 165-178, doi: https://doi/ 10.15294/lesrev.v5i1.42859

\section{History of Article}

Received: November 26, 2020

Revised: May 17, 2021

Accepted: May 27, 2021

(C) The Author(s)

\section{(c) (i) 8 (2)}

This work is licensed under a Creative Commons Attribution-NonCommercialShareAlike 4.0 International License. All writings published in this journal are personal views of the authors and do not represent the views of this journal and the author's affiliated institutions.

Lex Scientia Law Review published by Faculty of Law, Universitas Negeri Semarang, Indonesia in collaboration of UKM Lex Scientia. Published biannually every May and November.

\begin{abstract}
Dispute settlement through the courts (litigation) is perceived as ineffective and costly. The dispute resolution process through the courts is prolonged and time-consuming due to its very formal and very technical review procedure, high costs of the case, and the likelihood of repeated trials. The number of complaints made against citizens unwilling to deal with the judiciary. The Supreme Court with its authority to address the problems of the courts (litigation), namely by ratifying the 2015 Supreme Court Regulation (Perma) No. 2 concerning the procedures for the settlement of the Small Claims Court, to allow all elements of society to take a new direction of litigation, namely through Small Claims Court a simple, fast and low-cost lawsuit. With this, it hopes that the judicial process in Indonesia will be well underway in the future.
\end{abstract}

\section{KEYWORDS}

Dispute; Litigation; Small Claims Court; Supreme Court Regulation. 


\section{INTRODUCTION}

Dispute settlement in the court (litigation) is considered ineffective and costly to interrupt or delay business activities. The process of resolving disputes through the courts is prolonged and time-consuming due to a highly formal and highly technical system of examinations; the costs of the case are expensive, and the trial can take place many times.

From that point of view, in the opinion of the author, there is a need for a form of dispute settlement procedure, in particular business disputes, as is recognized in developed countries, by granting the court authority to resolve cases based on the scale of the object value of the dispute, so that it can be accomplished. Dispute resolution, particularly business, quickly, simply, and cheaply, through a process called the Small Claims Court. The dilemma is how to enforce dispute resolution procedures through the Small Claims Tribunal Process.

The Small Claim Court was founded by Cleveland Court in 1913 when the idea emerged as the first court to end the exploitation of the poor by offering peace-first justice in Cleveland. ${ }^{1}$

The loosely implemented Small Claim Court was implemented in the Norwegian conciliation court founded in 1797 to protect farmers from lawyers, who were believed to exacerbate wrongdoing and increase hostility between the parties at a very high cost. The first Small Claim Court in the United States was developed in the early twentieth century because of the formal, complex, and expensive civil justice processes that most income earners or small entrepreneurs could not use. ${ }^{2}$

The five main components of the background to the creation of the SCC in the United States: ${ }^{3}$ Reduction in court fees; simplification of the litigation application process; litigation procedures are primarily left at the discretion of the court judge, and the formal rules of the selected evidence; judges and court clerks are expected to be able to assist litigants both in preparations before going to court and in court, so that representation by lawyers will be

\footnotetext{
1 Septi Sari Wulan, "Penyelesaian Sengketa Melalui Small Claim Court", Ahkam: Jurnal Hukum Islam, Volume 4, 2016, p. 329.

2 Efa Laela Fakhriah, "Mekanisme Small Claims Court Dalam Mewujudkan Tercapainya Peradilan Sederhana, Cepat, Dan Biaya Ringan", Mimbar Hukum-Fakultas Hukum Universitas Gadjah Mada, Volume 25 Number 2, 2013, p. 265.

${ }^{3}$ Anita Afriana, "Penerapan Acara Singkat dan Acara Cepat dalam Penyelesaian Sengketa Perdata di Pengadilan: Suatu Tinjauan Politik Hukum Acara Perdata", ADHAPER: Jurnal Hukum Acara Perdata, Volume 1 Number 1, 2015, p. 36.
} 
largely unnecessary; and the judge is given the power to order direct installment payments in his decision.

Small Claims Court has been developed in both countries with Common Law System and Civil Law system. Small Claims Court has grown and developed rapidly in developed countries such as America, Canada, England, Germany, the Netherlands, Latin America, Africa, and Asia. ${ }^{4}$

The Supreme Court is a judicial institution with the legal authority to fill legal holes in the material that has not been governed by statute. It is governed by the Regulation of the Supreme Court (PERMA) as provided for in Article 79 of Law No. 14 of 1985 concerning the Supreme Court. ${ }^{5}$ As a judicial institution, the Supreme Court is empowered to create a law, but this authority is limited to the administration of justice. ${ }^{6}$ According to this Rule, the Supreme Court (MA) has released Supreme Court Regulation No. 2 of 2015 concerning the procedures for the settlement of the Small Claims Court, in the future abbreviated as Perma No. 2 of 2015.

Establishment of Supreme Court Regulation No. 2 of 2015 concerning the procedures for the settlement of the Small Claims Court, the background is from public complaints against costly and complicated civil procedural law practices. The number of complaints made by disputing people unwilling to deal with the judiciary, particularly those with low-value disputes. In fact, according to the principle, justice should be done efficiently, conveniently, and at a low cost. Here is a simple, sudden lawsuit to simplify the mechanism of civil procedural law, which has so far been deemed costly and complicated.

The idea of a simple case or a small claims court is a legal body (dispute resolution agency) designed to offer a fast and cost-effective solution to conflicts that do not entail high costs. The Small Claims Court is an informal dispute settlement venue, and the case fee is relatively cheaper, with a small case benefit. ${ }^{7}$

In general, the small claims court is often interpreted as a genuine "people's court." It is consistent with creating a small claims court to provide

\footnotetext{
${ }^{4}$ Bustamar, "Small Claim Court Dalam Sistem Peradilan Perdata Di Indonesia Dan Peluang Penerapannya Dalam Penyelesaian Sengketa Ekononomi Syari'Ah Pada Peradilan Agama", Al Hurriyah: Jurnal Hukum Islam, Volume 1 Number 1, 2016, p. 98.

${ }^{5}$ The Republic of Indonesia, Law Number 14 of 1985 concerning Supreme Court.

${ }^{6}$ Nur Sholikin, "Mencermati Pembentukan Peraturah Mahkamah Agung (Perma)", Rechts Vinding Online, Media Pembinaan Hukum Nasional, Jakarta, 2017, p. 1.

7 M. Yahya Harahap, Hukum Acara Perdata tentang gugatan, persidangan, penyitaan, pembuktian, dan putusan pengadilan, Sinar Grafika, Jakarta, 2005, p. 233.
} 
formalities for dispute settlement with a small claims value, uncomplicated case investigations to settle simple conflicts that do not require much money to guarantee formal litigation costs. In addition, all parties present their respective arguments to the judge. In general, the judge does not need to know the law itself to apply to a conflict of a fundamental nature.

In the explanation given above, the author wishes to clarify in depth the problems that exist in the court (litigation) in Indonesia and to find a solution to the problems of the court (litigation) by referring to Perma No. 2 of 2015 concerning the procedures for the settlement of the Small Claims Court.

The following research problems can be formulated based on the background of the problem as mentioned above:

1. What are the reasons people are reluctant to go through court proceedings in Indonesia?

2. Does the Supreme Court provide the solution through Perma No 2 of 2015? Can it be a way out for the Indonesian people to take the litigation path?

\section{METHOD}

The research method used in this research is legal normative. Normative legal research is a legal research method that involves the examination of library materials or secondary materials. This type of legal research is where the law is conceptualized as what is written in the statutory regulations (law in books) or where the law is conceptualized as a rule or norm that is a benchmark for human behavior that is considered appropriate. This research is a Normative Juridical Research on the Application of Basic Litigation in Dispute Resolution in Indonesia.

The data analysis approach shall be carried out by gathering data through the study of literature or secondary data, including primary legal materials, secondary legal materials, and tertiary legal materials, both in the form of documentation and the relevant laws and regulations relating to the normative legal analysis of the application of straightforward claims in dispute resolution in Indonesia. 


\section{RESULT AND DISCUSSION}

\section{A. The Cause of Society is Hesitant to Take the Path of Legal Action in the Indonesian Judiciary}

According to the Big Indonesian Dictionary (in the future referred to as $\mathrm{KBBI}$ ), the definition of a dispute is 1) something that causes a difference of opinion; quarrel; controversy. 2) dispute 3) case (in court). ${ }^{8}$ According to Nurnaningsih Amriani, a dispute is a dispute between the parties to the agreement due to a default made by one of the parties to the agreement. ${ }^{9}$ Meanwhile, according to Takdir Rahmadi, disputes are situations and conditions in which people experience disputes of a factual nature or disputes based on their perceptions. ${ }^{10}$

According to Black, "Dispute is a conflict or a controversy; a conflict of claims or rights; an assertion of a right, a claim on the one hand, and a statement of contrary claims or allegations on the other."11 Conflict is a disagreement, part of which is a conflict of demands or rights. The author appears to claim that a business dispute is a business dispute between an investor and his business partner in order to invest-disputes resulting from failure to meet the negotiated achievements or defaults. Apart from default, conflicts arise because of "acts against the law." Disputes or conflicts of opinion arise concerning the execution of accomplishments between the parties, and thus disputes can be seen as potential and causes that arise in the field. ${ }^{12}$

Dispute settlement techniques have been in operation since ancient times following the growth of human civilization. Gods have created humans with different characters, different ethnic groups, and these distinctions cannot distinguish human beings from conflicts, both with other human beings, their natural environment, and themselves. Essentially, conflict resolution can and is typically carried out in two ways, namely dispute

\footnotetext{
${ }^{8}$ Definition based on the Indonesian Dictionary (KBBI)

9 Nurnaningsih Amriani, Mediasi Alternatif Penyelesaian Sengketa di Pengadilan, Grafindo Persada, Jakarta, 2012, p. 13.

${ }^{10}$ Takdir Rahmadi, Mediasi: Penyelesaian sengketa melalui pendekatan mufakat, Rajawali Pers, Jakarta, 2010, p. 1.

${ }^{11}$ Black, as quoted I Made Widnyana, Alternatif penyelesaian sengketa (ADR), Fikahati Aneska bekerja sama dengan BANI (Badan Arbitrase Nasional Indonesia), 2009, p. 52.

${ }^{12}$ Khotibul Umam \& Tim Pustaka Yutisia, Penyelesaian Sengketa di Luar Pengadilan. Pustaka Yustisia, Yogyakarta, 2010, p.6.
} 
resolution by litigation institutions (in courts) and dispute resolution through non-litigation (out of court).

Dispute resolution by non-litigation, typically referred to as the Alternative Dispute Resolution (ADR) in America, is commonly referred to in Indonesia as the Alternative Dispute Resolution (APS). ${ }^{13}$ As has been written in Article 1 point 10 of the Arbitration Law and APS, it is explained that "alternative dispute resolution is a dispute settlement institution or difference of opinion through a procedure agreed by the parties, namely settlement outside the court through consultation, negotiation, mediation, conciliation, or expert judgment." Out-of-court dispute resolution (in Indonesia, known as APS) has a legal basis regulated in Law Number 30 of 1999 concerning arbitration. Although in practice, dispute resolution outside the court is a cultural value, habit, or custom of the Indonesian people, which is in line with the ideals of the Indonesian people as stated in the 1945 Constitution of the Republic of Indonesia.

Apart from using the non-litigation route, there is also a dispute settlement channel in which the laws and regulations do not provide a definition of litigation. However, it can be seen in Article 6(1) of Law No 30 of 1999 on arbitration, which essentially states that disputes in the civil sector can be resolved by the parties through alternative dispute resolution. ${ }^{14}$

Litigation conflict settlement is an attempt to settle conflicts by the institutions of the court. According to Dr. Frans Hendra Winart, S.H., MH. In his book Law of Dispute Resolution, it is claimed that litigation is traditional dispute resolution in the business world, such as trade, banking, mining, oil and gas, electricity, infrastructure, etc. The conflict mechanism pits the parties against each other. In addition, conflict resolution is the final means (ultimum remidium) following the failure of alternative dispute resolution attempts to achieve results. ${ }^{15}$

Dispute settlement by arbitration has both benefits and drawbacks. The conflict settlement mechanism in the courts creates an unfavorable decision that has not been able to take a common interest because it has resulted in a win-loss solution. So that there will undoubtedly be parties who win, the other party will lose, as a result of which there are some who feel happy and

\footnotetext{
${ }^{13}$ Rachmadi Usman, Mediasi di Pengadilan dalam Teori dan Praktik, Sinar Grafika, Jakarta, 2012, p. 8.

${ }_{14}$ The Republic of Indonesia, Law Number 30 of 1999 concerning Arbitration and Dispute Resolution Alternatives.

${ }^{15}$ Frans Hendra Winarta, Hukum penyelesaian sengketa: arbitrase nasional Indonesia dan internasional. Sinar Grafika, Jakarta, 2012, p. 1-2.
} 
those who are not in a position to trigger a new issue among the contested parties.

Not to mention the slow dispute settlement process, long-term and unpredictable costs, so that they can be relatively costly. The lengthy procedure is not only because the number of cases that need to be resolved is not equal to the number of employees in the court, but also because there are stages of legal recourse that can be taken by the parties as guaranteed by current laws and regulations in Indonesia, i.e., beginning at the first level of the District Court of Appeal. In the High Court case, the cassation in the Supreme Court and the last case for judicial review, so that the concept of quick, easy, and low-cost testing has not been achieved.

So that the government finally gave a solution by issuing Perma No. 2 of 2015 concerning the procedures for the settlement of the Small Claims Court, which can solve problems regarding the judiciary in Indonesia, especially in cases that often occur which cause the lack of Indonesian people to take the litigation path.

\section{B. Is Perma No. 2 of 2015 Can be a Way out for the Indonesian People in Taking the Litigation Path}

Dispute settlement by the court (litigation) is considered counterproductive and costly to interrupt or delay business activities. It is because the method of settling disputes in the courts is prolonged and timeconsuming as a result of a highly formal and highly complex system of examinations; costly case fees (considering that for the filing of a lawsuit there are about 500,000 rupiahs until 750,000 rupiahs various prosecution fees, legal fees, seizure fees, witness review fees, and other related costs). It has the potential to expand the dispute settlement process even though there are quick, transparent, and low-cost legal principles.

Out of the issues mentioned earlier, the Supreme Court (MA) has released Regulation No. 2 of the Supreme Court of 2015 on procedures for the resolution of Small Claims Court, abbreviated as Perma No. 2 of 2015. The word "simple lawsuit" is often widely referred to as the "small claims court," which is a minor civil suit with a quick case settlement procedure as is well established in developed countries, by granting the courts the power to settle disputes on the basis of the scale of the object value of the dispute, so that the dispute can be settled quickly, clearly and cheaply through a process called 
the Small Claims Court. The dilemma is if Perma No. 2 of 2015 can be a way out for the citizens of Indonesia to take legal action.

The Small Claims Court has long developed in both countries with standard law systems and civil law systems. Indeed it is growing and expanding rapidly not only in developed countries such as America, England, Canada, Germany, the Netherlands but also in developing countries such as Latin America, Africa, and Asia. The forum for conflict settlement through the courts is effective, quick, and low-cost in cases with a limited number of cases.

Several restrictions have been regulated in Perma No. 2 of 2015. ${ }^{16}$ For example, when filing a complaint, the maximum value of the object of the case is Rp. 200,000,000'-(two hundred million rupiahs) with a simple trial and presided over by a single judge. The time limit for the resolution of this case is no more than 25 working days and must have been determined. The verdict is definitive and binding on the first step. Nor is the process for filing a simple complaint required to be represented by a prosecutor or a lawyer, as is the case in ordinary civil cases. However, the parties (Plaintiff and Defendant), with or without a lawyer, are expected to be present in person during the trial. A case cannot, therefore, be brought if the defendant has no known home or domicile. Using the services of a lawyer, of course, is going to cost much money. The Regulation points out that the parties do not need to use the services of a lawyer to make the judicial process more successful and productive (litigation of effectiveness). This simple case is not meant as a dispute but instead seeks a fast and straightforward solution to the legal issues faced by the parties.

The administration of justice is based on the ideals of easy, rapid, and low-cost access to justice for the general public. It is one of the considerations of the Supreme Court in making significant breakthroughs in the interests and services of the society. The terms of the Simple Suit are as follows: ${ }^{17}$

1. The amount of the content lawsuit is no more than IDR 200,000,000 (two hundred million rupiahs).

2. Easy litigation cases include default/default cases or unauthorized acts against the law cases with a maximum material claims value of $\mathrm{Rp}$. 200,000,000,-two hundred million rupiahs.

3. It is not a court case where the issue is expressly settled.

\footnotetext{
16 The Republic of Indonesia, Supreme Court Regulations Number 2 of 2015 concerning Settlement Procedures Small Claim.

17 Sherly Ayuna Putri, "Penyelesaian Sengketa Perdata Melalui Gugatan Sederhana Berdasarkan Perma No. 2 Tahun 2015", Jurnal Pengabdian Kepada Masyarakat, Volume 2 Number 12, 2018, p. 3.
} 
4. No conflict over property rights.

5. Any party, namely the Complainant and the Defendant, should not be more than one (one) because it has the same legal interest.

6. The parties, either the plaintiff or the defendant, are domiciled in the same jurisdiction.

7. In the case that the Resident of Defendant is not identified, a simple complaint cannot be brought.

8. The participants, either the plaintiff or the defendant, are expected to attend every trial directly, with or without the assistance of their legal counsel.

9. The plaintiff lodged his claim with the Registrar's Office of the Court of Justice.

10. When registering his claim, the plaintiff may fill in the form of a claim issued by the Registrar of the Court.

11. The type of complaint contains material, namely the Plaintiff's Identity, the Defendant, the Brief Description of the Setting of the Case, and the Plaintiff's Claims.

12. In a clear hearing, charges for provision, exception, interference, intervention, repetition, duplicate, or inference cannot be filed.

13. Plaintiffs are allowed to attach documentary proof that was legalized at the time of basic filing of a lawsuit.

14. The applicant is obliged to pay a down payment fee.

15. In the event that the applicant is incapacitated, the applicant can request a free or prodeo application.

Based on the explanation above, it is hoped that the Small Claims Court will be an alternative to settle lawsuits on the basis of simple, easy, and inexpensive legal principles and that it may eliminate complicated and structured litigation procedures. ${ }^{18}$ So that as the process progresses to a new case, hereinafter referred to as the Simple Lawsuit, which Perma governed Number 2 of 2015 concerning the procedures for the settlement of the Small Claims Court, it is expected that a solution can be found to the issues that occur in our country because in this simple judicial process, as mentioned above, it does not require a great deal of money to trigger a middle and lower class society.

${ }^{18}$ Dian Latifiani, "The Small Claim Court To Realize The Fast And Simple Principle In Civil Disputes Resolution," South East Asia Journal of Contemporary Business, Economics and Law, Volume 18 Number 4, 2019 , p. 9. 


\section{CONCLUSION}

There are two ways to settle a dispute in Indonesia through litigation institutions (in courts) and non-litigation (out-of-court) dispute settlement. Litigation conflict settlement is an attempt to settle conflicts by the institutions of the court. Dispute resolution through the courts (litigation) is known to be ineffective and costly because the dispute resolution process through the courts is prolonged and time-consuming as a result of its highly formal and highly technical examination system; the costs of lawsuits are high, and court rulings often do not solve problems, but instead generate new problems, provided that the litigation method does not solve problems. It has the potential to expand the dispute settlement process even though there are quick, transparent, and low-cost legal principles. The Supreme Court (MA) has released Regulation Number 2 of the Supreme Court of 2015 concerning the procedures for the settlement of the Small Claims Court, which is considered to be remedied for the group so that they can use the mechanisms of litigation to resolve their disputes since the group had previously been hesitant to use the litigation route because it perceived that the litigation route was ineffective and costly. The administration of justice is based on the ideals of easy, rapid, and low-cost access to justice for the general public. It is one of the considerations of the Supreme Court in making significant breakthroughs in the interests and services of the society. The word "simple lawsuit" is usually referred to as the "small claims court" as it is known in developed countries by granting the court the power to resolve disputes on the basis of the scale of the object value of the dispute so that that dispute settlement can be done quickly, simply, and cheaply through a process. It is the so-called Small Claims Court.

\section{DECLARATING OF CONFLICTING INTEREST \\ None}

\section{FUNDING INFORMATION}

None 


\section{ACKNOWLEDGEMENT}

We would like to express our gratitude to our parents and colleagues of Lex Scientia Law Review, Faculty of Law, State University of Semarang which always supported us, so that this research article can be completed properly.

\section{REFERENCES}

Afriana, A. (2015). Penerapan Acara Singkat dan Acara Cepat dalam Penyelesaian Sengketa Perdata di Pengadilan: Suatu Tinjauan Politik Hukum Acara Perdata. ADHAPER: Jurnal Hukum Acara Perdata, 1(1), 3143.

Amriani, N. (2012). Mediasi Alternatif Penyelesaian Sengketa di Pengadilan. Jakarta: Grafindo Persada.

Black, as quoted Widnyana, I. M. (2009). Alternatif penyelesaian sengketa (ADR). Fikahati Aneska in collaboration with BANI (Badan Arbitrase Nasional Indonesia).

Bustamar, B. (2016). Small Claim Court Dalam Sistem Peradilan Perdata Di Indonesia Dan Peluang Penerapannya Dalam Penyelesaian Sengketa Ekononomi Syari'Ah Pada Peradilan Agama. Al Hurriyah: Jurnal Hukum Islam, 1(1), 85-108.

Fakhriah, E. L. (2013). Mekanisme Small Claims Cortt Dalam Mewujudkan Tercapainya Peradilan Sederhana, Cepat, Dan Biaya Ringan. Mimbar Hukum-Fakultas Hukum Universitas Gadjah Mada, 25(2), 258-270.

Harahap, M. Y. (2005). Hukum Acara Perdata Tentang Gugatan. Persidangan, Penyitaan, Pembuktian, dan Putusan Pengadilan. Jakarta: Sinar Grafika.

Kamus Besar Bahasa Indonesia (KBBI).

Latifiani, D. (2019). The Small Claim Court To Realize The Fast And Simple Principle In Civil Disputes Resolution. South East Asia Journal of Contemporary Business, Economics and Law, 18(4), 9.

Putri, S. A. (2018). Penyelesaian Sengketa Perdata Melalui Gugatan Sederhana Berdasarkan Perma No. 2 Tahun 2015. Jurnal Pengabdian Kepada Masyarakat, 2(12), 3.

Rahmadi, T. (2010). Mediasi: Penyelesaian sengketa melalui pendekatan mufakat. Jakarta: Rajawali Pers.

Sari, S. W. (2016). Penyelesaian Sengketa Melalui Small Claim Court. Ahkam: Jurnal Hukum Islam, 4, 329. 
Sholikin, N. (2017). Mencermati Pembentukan Peraturah Mahkamah Agung (Perma). Rechts Vinding Online, Media Pembinaan Hukum Nasional, Jakarta, 1.

The Republic of Indonesia. (1985). Law Number 14 of 1985 concerning the Supreme Court. State Gazette of the Republic of Indonesia of 1985 Number 73, supplementing the State Gazette of the Republic of Indonesia Number 4958.

The Republic of Indonesia. (1999). Law Number 30 of 1999 concerning Arbitration and Dispute Resolution Alternatives. State Gazette of the Republic of Indonesia Year 1999 Number 138, Supplement to State Gazette of the Republic of Indonesia Number 3872.

The Republic of Indonesia. (2015). Supreme Court Regulations Number 2 of 2015 concerning Settlement Procedures Small Claim.

Umam, K., \& Yutisia, T. P. (2010). Penyelesaian Sengketa di Luar Pengadilan. Yogyakarta: Pustaka Yustisia.

Usman, R. (2012). Mediasi di Pengadilan dalam Teori dan Praktik. Jakarta: Sinar Grafika.

Winarta, F. H. (2012). Hukum penyelesaian sengketa: arbitrase nasional Indonesia dan internasional. Jakarta: Sinar Grafika. 


\section{ABOUT AUTHOR(S)}

Seno Adhi Wibowo, born in Kulon Progo, Yogyakarta Special Region, May 6, 2000, is a student of the Faculty of Law, State University of Semarang batch 2018. Active on campus by joining various organizations and student activity units, including the English Discussion Community, the Student Representative Council of the Faculty of Law, and the Student Executive Board of the Semarang State University Student Family. He is also active in committee activities held in the campus internal environment, such as TOEFL and Workshop, TOEFL and Scholarship Virtual Workshop, Faculty of Law Student Congress 2020. The competitions he has participated in are International Model United Nations at the British University of Vietnam and several other competitions.

Massulthan Rafi Wijaya, born in Semarang, Central Java, May 23, 2000 is a student of the Faculty of Law, State University of Semarang. Active on campus by joining various organizations and student activity units, including becoming a Director at BSO Entrepreneurship and becoming a member in the English Discussion Community. He is also active in committee activities organized by the UKM UPS (Mutual Justice Unit) of the Faculty of Law, UNNES with a national scope with a program called the Conservation Cup. 


\section{LEGAL ADAGE}

\section{LEX SEMPER DABIT REMEDIUM}

\section{The Law Always Provide Cure}

